\title{
Effectiveness of Multitrack Diplomacy Actors in Critical Assessment of Kenya's Presidential Election Outcomes, 2007-2017
}

\author{
David Owuor Okoth Sanmac ${ }^{1}$, Pontian Godfrey Okoth $^{2}$, Elijah Onyango Standslause Odhiambo ${ }^{3}$ \\ ${ }^{1}$ School of Disaster Management and Humanitarian Assistance, Masinde Muliro University of Science and Technology, Kakamega, Kenya \\ ${ }^{2}$ Department of Peace and Conflict Studies, School of Disaster Management and Humanitarian Assistance, Masinde Muliro University of \\ Science and Technology, Kakamega, Kenya \\ ${ }^{3}$ Department of Political Science and International Relations, School of Arts and Social Science, Bomet University College, Bomet, Kenya
}

\section{Email address:}

sanmac2005@yahoo.com (D. O. O. Sanmac), pokoth@mmust.ac.ke (P. G. Okoth), standslauseodhiambo@yahoo.com (E. O. S. Odhiambo)

\section{To cite this article:}

David Owuor Okoth Sanmac, Pontian Godfrey Okoth, Elijah Onyango Standslause Odhiambo. Effectiveness of Multitrack Diplomacy Actors in Critical Assessment of Kenya's Presidential Election Outcomes, 2007-2017. Journal of Political Science and International Relations. Vol. 4, No. 3, 2021, pp. 83-95. doi: 10.11648/j.jpsir.20210403.13

Received: June 25, 2021; Accepted: July 5, 2021; Published: August 23, 2021

\begin{abstract}
In Kenya's last four presidential elections, election observers had been seriously looked upon by both the Kenyan voters and the international community to provide alternative but credible information on the process and outcomes of presidential elections in Kenya. This was expected to promote legitimacy of the outcomes. Given that there was a dearth of specific scholarship to address the question, this study was conducted. This paper therefore examines the effectiveness of multitrack diplomacy in monitoring Kenya's presidential election outcomes. The study was epistemological. It was conducted in 8 of the 17 constituencies of Nairobi City County which hosts the Kenya's largest city and its capital with a natural representation of the population of the entire country. Out of the over 4 million residents of Nairobi City County, total sample size was 441 (384 questionnaire respondents, 32 focus group discussion participants and 25 key informant interview respondents). The study reached 436 (384 questionnaire respondents, 32 focus group discussion participants and 20 key informant interview respondents) out of 4 million people. Targeted were Kenya citizens who had voted at least once for a presidential candidate in any of the presidential elections held between 2007 and 2017 for the survey; individuals working with and for government institutions in Kenya's electoral systems especially the election management body, ministry of foreign affairs, members of parliament, the Chief Justice, pollsters, the media, non-governmental organizations, religious institutions across all faiths as to Muslims, Christians and Hindu, major political parties, former election observers and diplomatic missions. The study found that multitrack diplomacy (MTD) actors or election observer missions (EOMs) observed election irregularities to above $50 \%$. They detected electoral fraud in the 2007 presidential elections, identified election irregularities in the 2013 and the 2017 presidential elections but could not deter nor prevent outcome fraud. The paper, based on the study, concluded that multitrack diplomacy actors that monitored the presidential elections were fairly effective, they had reasonable capacity, fairly above $50 \%$. Overall, multitrack diplomacy is effective in monitoring of Kenya's presidential election but inefficacious in preventing and deterring election outcome fraud. Multitrack diplomacy actors-the election observation missions (EOMs) to use enhanced technology to match the electoral systems technology, improve on their objectivity during monitoring and be granted full accesses by governments and election management bodies (EMBs) for systematic, comprehensive and accurate monitoring.
\end{abstract}

Keywords: Accurate, Assessment, Capacity, Comprehensive, Critical, Systematic

\section{Introduction}

The actors which participate in monitoring or observing elections can be identified as multi-track diplomacy (MTD) actors $[18,16,5]$. For effective monitoring of elections, the monitors must have requisite capacities for the systematic, 
comprehensive, accurate, impartial and professional observation required of them. This should enable them to act as deterrence to electoral fraud, detect and prevent fraud from the pre-election observation to post-election reporting [27]. For election observation to pass the test of credibility, the observer missions must ask themselves a number of questions and find answers for all the questions such that failure to find answer even for just 1 of the questions invalidates the credibility of their observation [7, 25].

Kenya's presidential elections have been monitored. However, the outcomes of the ones conducted in 2007, 2013 and 2017 were contested by the losing wing and their supporters on the basis of fraud, despite having been monitored by multi-track diplomacy actors most of which gave positive endorsement to results. This paper therefore, examines the effectiveness of multi-track diplomacy in critical assessment of Kenya's presidential election outcomes. In the next section, the methodology used is discussed.

\subsection{Statement of the Problem}

A number of scholars retort that it is a prominent tool for promoting election integrity and democracy and can also promote public confidence in an election $[13,18]$. But it can portray biases legitimizing governments born out of questionable elections [15], endorse a flawed election [9] and may greatly differ from public assessments [21]. This casted questions on MTD actors' capacities for the systematic, comprehensive and accurate monitoring of Kenya's presidential elections whose outcome specifically the August 2017, the March 2013 and the December 2007 were disputed, termed 'rigged' and 'fraudulent' by the opposition. For the August 2017, the results were nullified by the Supreme Court despite being judged as free and fair by majority of election observers including high ranking diplomats in Kenya. Against this bleak picture, the effectiveness of MTD actors in critical assessment of Kenya's presidential election outcomes ought to be examined.

\subsection{Objective of the Study}

The objective of the study was to investigate the effect of election monitoring by MTD actors on the outcome of Kenya's 2007, 2013 and 2017 presidential election. Specifically, the study examined their effectiveness in election observation.

\subsection{Research Question}

The main research question was: what effect does election monitoring by MTD actors on Kenya's 2007, 2013 and 2017 presidential election outcomes? the specific question was: how effective are MTD actors in election observation?

\subsection{Justification of the Study}

In Kenya's last four presidential elections, election observers had been seriously looked upon by both the Kenyan voters and the international community to provide alternative but credible information on the process and outcomes of presidential elections in Kenya. This was expected to promote legitimacy of the outcomes. There was however, a dearth of scholarship on the effectiveness of MTD actors in critical assessment of Kenya's 2007, 2013; and 2017 presidential elections whose outcomes, despite having been monitored by many election observers, were questioned. The fact that the next presidential elections were slated for 2022; this study was needed to yield policy recommendations. The philosophical justification was drawn from the 'untested' view that election observation can enhance legitimacy of election.

\subsection{Scope of the Study}

This study was limited to assessing the efficacy of MTD election observation as a tool for that monitored Kenya's presidential elections. Specifically, it focused on the 2007, 2013, August 2017 presidential election in Kenya. It narrowed down on sampling politically important case the most suitable for studying elections. Out of all the elections for the president in Kenya since independence, these three different years' elections were the most striking.

\section{Literature Review}

This section has two sub-headings: literature review on the effectiveness of MTD actors in monitoring election outcomes with the view to enhancing legitimacy of elections and the conceptual model.

\subsection{Effectiveness of MTD Actors in Critical Assessment of Elections}

The United Nations in its 'Declaration of Principles for International Election Observation' on election monitoring states: "Genuine democratic elections are an expression of sovereignty, which belongs to the people of a country, the free expression of whose will provides the basis for the authority and legitimacy of a government," [6]. Election observation is fundamentally an exercise in support of this principle. International observers serve as impartial watchdogs that can assess whether the results of an election truly reflect the will of the people.

According to Kelley [14], there are three outcomes of election observation: the 'good', the 'bad' and the 'ugly'. The 'good' outcome of election observation is in its ability to improve the quality of elections since empirically, election observation has deterrent effects on electoral fraud as earlier contended by Hyde [10]. The 'bad' outcome, Kelley contends, is that election observation does not improve the quality of elections; while, the ugly outcome is that election observation may manifest biases therefore legitimizing governments arrived at through electoral fraud [14].

The general picture painted by Kelley's findings is that elections in Africa are not free and fair therefore lack credibility and integrity while international election observation does not deter or detect electoral malpractices, in case it does, it is ineffective and worthless. Although the 
conclusion is generalizable, it is imperative to critically analyse and understand Kenya's case given that Kelley does not focus on it [14].

Otieno et al. set out to investigate 'the good', 'the bad' and 'the ugly' implications of the 2013 elections. However, they did not bring out these implications and the study did not attempt to critically critique the role and effectiveness of international election observers pre-cautiously ahead of the 2017 elections of which the credibility and integrity remain questionable to date [26].

Muna \& Hong details the ideal role of international election observer missions arguing that, "They are expected to provide an accurate and impartial reporting or assessment of the quality of elections. They are expected publish their findings and offer recommendations for improvement of future elections. Election observation monitors are also expected to be a symbol of support from the international community to a given country [16]."

While Shah recommends mediation of the standards of international and local election observation she contradicts the point arguing that it is the local observers' verdict that matters in legitimizing elected governments. These divergent views complicate the understanding of the role and therefore effectiveness of international election observation warranting this study to establish a clear position their role and significance [27].

Muna \& Hong outline the parameters for evaluating the effectiveness and outcome of international election observer missions: they are expected to provide an accurate and impartial reporting or assessment of the quality of elections; to publish their findings and offer recommendations for improvement of future elections [16].

Further, while Kelley alludes to possible interference, they do not pin-point any evidence in this respect and therefore are merely speculative without attempting to investigate using a specific empirical case [14].

While Muna \& Hong do not dispute the independence of election observers, they imply that election observers are partisan especially the international ones but without facts ( $p$. 1). The misnomer is that they do not 'accuse' them of breaching the prescribed "code of conduct of international observers and local, regional and international standards and democratic practices [17]".

Damdinjav et al. while 'blaming' the disputed 2007 presidential elections on institutional failure contends that the international election observation groups or missions were left wondering what could have happened [6]. In a nutshell, they do not question the effectiveness of international election observer missions as well as level of impartiality, independence and professionalism.

From the studies, the context of monitoring the outcome of presidential elections by MTD actors with a view to enhancing the legitimacy of the elections, the efficacy of MTD is yet to be critically assessed. Nonetheless, the applicability and effectiveness of MTD as conflict management and resolution strategy is devoid of credibility, accuracy and legitimacy [19]. Therefore, the effectiveness of multi-track diplomacy (MTD) as a conflict resolution and management have sparked an elusive debate.

\subsection{Conceptual Model}

This conceptual model was drawn from three theories: liberal democratic theory, power theory and social choice theory. The independent variable was effectiveness MTD actors in election monitoring. The dependent variable was election outcome. The intervening variable was Level of host state cooperation in the elections. Figure 1 illustrates this.

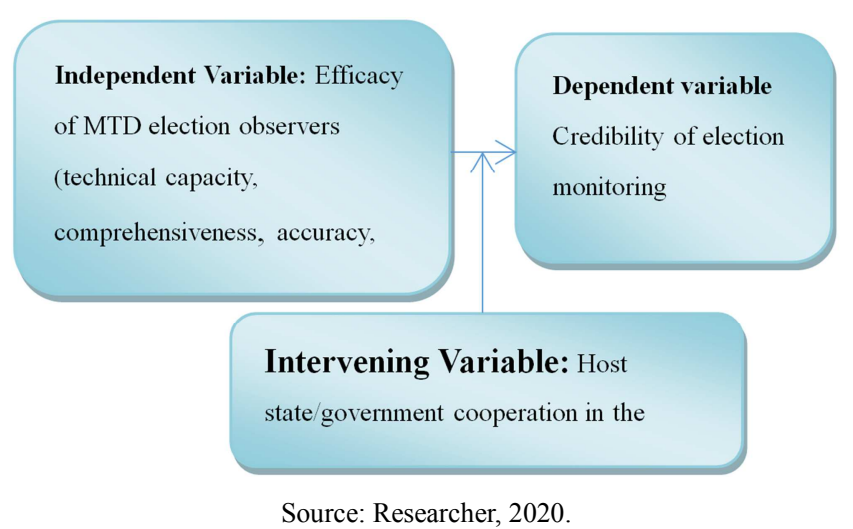

Figure 1. Conceptual Model.

\section{Methodology}

The study from which this paper emanates was epistemological and was conducted both from primary data and secondary data approaches. Primary data was collected from voters and relevant government and non-governmental institutions in Nairobi. Questionnaire was administered among 384 individual voters in 8 out of the 17 constituencies comprising Nairobi City County, where Kenya's seat of power rests. Focus group discussions with 32 participants were held and as well, key informant interviews with 20 participants were conducted. The total sample size of the population reached was 436 from a sample size of 441 . Secondary data was collected taking care of the reliability, sufficiency and accuracy of the data with the dependent variable and the independent variable in mind. Quantifiable data were analysed using descriptive statistics by aid of statistical packages for social sciences (SPSS) while qualitative data were analysed using content analysis. Findings were presented in form of tables, figures, figures and narratives. In the next section the findings are presented and discussed.

\section{MTD EOMs' Capacity for Systematic, Comprehensive and Accurate Monitoring}

During Kenya's 2007 elections, a number of election observation teams ranging from the National Democratic Institute (NDI), the International Republican Institute (IRI), 
the Commonwealth EOM, the EU EOM, while they were able to monitor many aspects of the electoral process, the EMB created certain barriers which affected their monitoring especially the critical aspect of vote tallying. The IRI wrote, "Following transfer of ballot boxes,...some areas officials turned off their cells phones ...manipulation of the results of presidential poll...ECK refused to allow observers into tallying areas...government instituted media blackout until sudden announcement of Kibaki as winner,...furthered suspicions of malfeasance [12].

However, according to the EMB, the observers for all the elections in the country since the December 2002 elections were accorded the environment to ensure the questions were addressed at least from the side of the EMB. According to an IEBC officer, there were no forms of obstructions or restrictions or conditions created by the EMB to hamper operations of election observers both international and local. The officer remarked, "...no one was restricted from accessing the server...I can show you who was given access, how many times they logged into the server.... IEBC accredited over 58,000 observers and did not restrict any....(Interview, Nairobi, November 25, 2020).

This argument was in tandem with the post-election evaluation report of the EMB in which it was noted that: "In the 2017 General and Fresh Presidential elections, the Commission accredited a total of 58,308, out of which 6,400 were long term observers while 51,308 were short term," [11] and an argument by a senator who remarked that the IEBC on presidential elections was more prone to internal influence than foreign influence right from the political way in which they are constituted and the politically slotted commission seats. He said,

...independence of IEBC from influence...you would have asked, how independent is IEBC from internal influence because... the internal influence is more than foreign influence...we have seen the EMB in Kenya behaving in a partisan way...from the manner in which they even communicate to candidate in the oppositions... treat the candidates even prior to the elections...we have seen the president intimidate the IEBC, some of the commissioners and staff being assassinated...we have not achieved independence of the EMB.... unfortunately BBI is not going to address that because even the published bill has not looked into that...am not optimistic that electoral justice will be better that where we were more than ten (10) years ago (Interview, Nairobi, December 5, 2020).

For the December 2002 in particular, Commonwealth Secretariat (2006) confirmed Commonwealth Election Observer Group alongside a plethora of foreign and local observer missions were accorded the freedom and opportunity to monitor the elections. The Commonwealth Secretariat wrote,
In particular we wish to thank the Electoral Commission of Kenya, its District Election Co-ordinators and polling station officials and the police. Without their co-operation our work would have been impossible. We are most grateful to the political parties, non-governmental organisations, Commonwealth High Commissioners and others who briefed us in Nairobi before we were deployed and to the other international observers, with whom we worked closely in the field in order to maximise the effectiveness of our observation effort $[3,2]$.

In addressing the first specific objective and research question, specific questions were cast: how technical, professional, impartial and integral were the MTD actors who monitored Kenya's presidential elections of December 2007, March 2013, August 2017 and October 2017? The researcher analysed responses from the survey questionnaire, focus group discussion and key informant interviews. Therefore, the study examined the effectiveness of multitrack diplomacy in critical assessment of electoral process and prevention of electoral fraud in Kenya.

Specific concerns were how multi-track diplomacy actors including international and local observation teams had contributed to the democratic critical assessment of processes and credibility of the outcomes of Kenya's 2007, 2013 and 2017 presidential elections; how effective they had been in the determination of the credibility and integrity of presidential elections in Kenya; what techniques they employed and what their strengths and weaknesses were; how limited they were; and how the limitations affected their observation.

The August 2017 presidential election was basically a race between Kenyatta (incumbent) and Odinga (leading doyen of opposition politics) who ran against Kibaki (then incumbent) in December 2007 presidential elections. The results of both elections were disputed by Odinga leading to widespread violence between and among supporters of either side and the police and military against Odinga's supporters.

\subsection{EOMs' Capacity Towards Free and Fair Judgement of Elections}

Looking at Kenya's August 2017 presidential election, judgement of majority of the multitrack diplomacy actors who observed the election was that the election was free and fair and that the results were credible. However, the results were disputed by Odinga leading to widespread violence between and among supporters of either side and the police and military against Odinga's supporters. The study sought views of respondents who voted in August 2017 elections on the freeness and fairness of the election and credibility of its results. The views were summarized as shown in Table 1. 
Table 1. Views and manipulation of Kenya's August 2017 presidential election.

\begin{tabular}{|c|c|c|c|c|c|c|c|}
\hline & & \multicolumn{6}{|c|}{ Do you believe the results of August 2017 presidential election were manipulated? } \\
\hline & & Yes & & No & & Tota & \\
\hline \multirow{9}{*}{ Constituency Name } & Starehe & 31 & $64.6 \%$ & 17 & $35.4 \%$ & 48 & $100.0 \%$ \\
\hline & Westlands & 28 & $58.3 \%$ & 20 & $41.7 \%$ & 48 & $100.0 \%$ \\
\hline & Dagoreti North & 23 & $47.9 \%$ & 25 & $52.1 \%$ & 48 & $100.0 \%$ \\
\hline & Kibra & 22 & $45.8 \%$ & 26 & $54.2 \%$ & 48 & $100.0 \%$ \\
\hline & Langata & 35 & $72.9 \%$ & 13 & $27.1 \%$ & 48 & $100.0 \%$ \\
\hline & Mathare & 17 & $35.4 \%$ & 31 & $64.6 \%$ & 48 & $100.0 \%$ \\
\hline & Ruaraka & 30 & $62.5 \%$ & 18 & $37.5 \%$ & 48 & $100.0 \%$ \\
\hline & Embakasi East & 22 & $45.8 \%$ & 26 & $54.2 \%$ & 48 & $100.0 \%$ \\
\hline & Total & 208 & $54.2 \%$ & 176 & $45.8 \%$ & 384 & $100.0 \%$ \\
\hline
\end{tabular}

Source: Field Data, 2020.

From Table 1, majority $208(54.2 \%)$ of the respondents said that they believed that all the votes cast in the August 2017 presidential election counted and that the results were not manipulated while $176(45.8 \%)$ of the respondents had a contrary opinion. The percentage age difference of $8.4 \%$ between voter-respondents who believed their vote in the August 2017 presidential election counted (54.2\%) and those who held contrary belief (45.8\%) is telling. If these were results of a "mock repeat vote" then the results as announced by the EMB would be nearly $100 \%$ confirmed if the factors around the elections were held constant and only the two candidates (Kenyatta and Odinga) were the only presidential election contenders because in the contested elections,
Kenyatta got exactly $54.17 \%$ while Odinga garnered $44.94 \%$ of total valid votes [11]. To this extent, the judgements of the observers were describable as accurate, demonstrating their good capacity for critical judgement of Kenya's presidential election outcome.

\subsubsection{Sufficiency of MTD EOMs' Tactical Mapping}

The study investigated whether respondents believed the International election observer missions to Kenya's December 2007, March 2013, August 2017 and October 2017 presidential elections did insufficient tactical mapping. Their responses were summarized and presented as shown in Table 2.

Table 2. Sufficiency of MTD EOMs'tactical mapping.

\begin{tabular}{|c|c|c|c|c|c|c|c|}
\hline & & \multicolumn{6}{|c|}{ Do you believe international EOMs did insufficient tactical mapping for the observation? } \\
\hline & & Yes & & No & & Total & \\
\hline \multirow{3}{*}{ Gender } & Male & 150 & $77.3 \%$ & 44 & $22.7 \%$ & 194 & $100.0 \%$ \\
\hline & Female & 139 & $73.5 \%$ & 50 & $26.5 \%$ & 189 & $100.0 \%$ \\
\hline & Total & 289 & $75.3 \%$ & 95 & $24.7 \%$ & 384 & $100.0 \%$ \\
\hline
\end{tabular}

Source: Field Data, 2020.

Findings from Table 2 shows that majority $289(75.3 \%)$ of the respondents of whom $139(73.5 \%)$ and $150(77.3 \%)$ were female and male respectively, believed election observer missions to Kenya's December 2007, March 2013, August 2017 and October 2017 presidential elections did not do sufficient tactical mapping for the observation. Out of the total number of respondents who participated in the survey, $95(24.7 \%)$ of whom $50(26.5 \%)$ and $44(22.7 \%)$ were female and male respectively, did not believe so.

\subsubsection{Ability to Detect, Prevent and Deter Election Fraud}

As to whether there were irregularities that amounted to fraud in the processes and outcome of the August 2017 presidential election, the study sought to establish if the respondents believed that statements by Odinga and his National Super Alliance (NASA) and of Election Observation Group (AfriCOG) citing irregularities and manipulation of the outcome of the August 2017 presidential election were true. Table 3 gives detailed summary of the views of the voters.

Table 3. Voters'views on alleged fraud in Aug. 2017 presidential elections.

\begin{tabular}{|c|c|c|c|c|c|c|c|}
\hline & & \multicolumn{6}{|c|}{ Do you believe irregularities cited by NASA and AfriCOG in August 2017 election did not amount to outcome manipulations? } \\
\hline & & Yes & & No & & Tota & \\
\hline \multirow{3}{*}{ Gender } & Male & 109 & $56.2 \%$ & 85 & $43.8 \%$ & 194 & $100.0 \%$ \\
\hline & Female & 113 & $59.3 \%$ & 77 & $40.7 \%$ & 190 & $100.0 \%$ \\
\hline & Total & 222 & $57.8 \%$ & 162 & $42.2 \%$ & 384 & $100.0 \%$ \\
\hline
\end{tabular}

Source: Field Data, 2020.

From Table 3, majority $222(57.8 \%)$ of the respondents believed that statements citing irregularities and manipulation of the outcome of the August 2017 presidential election were true to the extent of presence of electoral malpractices but not to the extent of outcome fraud. 162 (42.2\%) of the respondents had a contrary opinion. Related information were obtained from most of the key informant interview respondents particularly from the civil society. One of them said: 
None of the 2007, 2013 and 2017 presidential elections was free and fair...... reports by certain election monitoring entities that the elections were free and fair and that their results were credible, were not true...reports from most local observers such as KNCHR and AfriCOG which discredited the processes and the results were more authentic than of international observers such as The Carter Center...... they could have lost objectivity either due to the interest of their sending/sponsoring entities and home states, or they might have been compromised by the government of the day in Kenya (Interview, Nairobi, October 22, 2020).

What came out of the analyses was that if these views were to stay then the reports of international observers and ELOG for example the case of the August 2017 presidential election in which they cited gaps in the election process and in observation itself contradict the positions maintained by the respondents across the three techniques used to gather information and nullifies the information itself. However, this disparity could be explained. A few of respondents particularly for key informant interviews exhibited personal biases; and while well-educated and by practice were political; this revelation pointed to their ignorance of the reports of the observers nearly all of which although declared the August 2017 as free and fair in tandem with the majority $(51 \%)$ of the voter-respondents confirmed, identified elements of irregularities which majority (57\%) of the respondents argued did not amount to outcome fraud.

The other thing that might have been forgotten by those who held belief on the negative was that election observers may have identified but could not prevent electoral fraud and that is a link that had been missing in comprehending their role by section Kenyan voters.

\subsubsection{MTD EOMs' Reliance on Convenience in Monitoring Processes in Kenya}

The study sought views of the respondents on comprehensiveness of MTD EOMs monitoring processes in Kenya with regards to the presidential elections of 2007, 2013 and 2017. Responses of the respondents were analyzed presented as shown in Table 4.

Table 4. MTD EOMs reliance on convenient techniques to monitor election outcome.

\begin{tabular}{|c|c|c|c|c|c|c|c|}
\hline & & \multicolumn{6}{|c|}{$\begin{array}{l}\text { Do you believe election monitors for Kenya's December 2007, March 2013, August } 2017 \text { and October } 2017 \\
\text { presidential election relied on convenient techniques and information to judge the election processes and outcome? }\end{array}$} \\
\hline & & Yes & & No & & Total & \\
\hline \multirow{8}{*}{$\begin{array}{l}\text { Constituency } \\
\text { Name }\end{array}$} & Starehe & 32 & $66.7 \%$ & 16 & $33.3 \%$ & 48 & $100.0 \%$ \\
\hline & Westlands & 38 & $79.2 \%$ & 9 & $18.8 \%$ & 48 & $100.0 \%$ \\
\hline & Dagoreti North & 35 & $72.9 \%$ & 13 & $27.1 \%$ & 48 & $100.0 \%$ \\
\hline & Kibra & 40 & $83.3 \%$ & 8 & $16.7 \%$ & 48 & $100.0 \%$ \\
\hline & Langata & 45 & $93.8 \%$ & 3 & $6.3 \%$ & 48 & $100.0 \%$ \\
\hline & Ruaraka & 28 & $58.3 \%$ & 20 & $41.7 \%$ & 48 & $100.0 \%$ \\
\hline & Embakasi East & 30 & $62.5 \%$ & 18 & $37.5 \%$ & 48 & $100.0 \%$ \\
\hline & Total & 292 & $76.0 \%$ & 92 & $24.0 \%$ & 384 & $100.0 \%$ \\
\hline
\end{tabular}

Source: Field Data, 2020.

From Table 4, majority 292 (76\%) of the respondents said that international election observation for Kenya's December 2007, March 2013, August 2017 and October 2017 presidential election has lacked comprehensiveness therefore relying on convenient techniques and information to judge the election processes and outcome while $92(24 \%)$ of the respondents disagreed. It followed therefore that a number of foreign observers experienced capacity inadequacies and restrictions that affected their ability to monitor certain aspects of the election processes while domestic/national/local observer missions/teams had well distributed and locally competent observers and with access to monitor outcome aspect of the process of elections. The EU EOM, IRI, among other foreign EOMs relied on local observation teams to conclude their observations on the election. IRI wrote,

The most detailed published material about election fraud during the 2007 Kenyan elections is the report from KEDOF observers stationed at the KICC during the immediate post-election period. A good summary of the conclusions by KEDOF observers, the European Union observer group and other international observer missions was set forth in the February 7, 2008 testimony of David Mozersky, Horn of Africa Project Director for the International Crisis Group, to the U. S. Senate Committee on Foreign Affairs [12].

With regards to its challenges to effectively and independently monitor the 2017 presidential elections, The Carter Center further observed:

While the lack of IEBC polling-station data hindered the parties' ability to verify results, it is important to note that a Kenyan citizen election observation organization (Election Observation Group, or ELOG) conducted a parallel vote tabulation that provided an independent verification of the official results. ELOG's tabulation was based on results data gathered from a representative random sample collected by about 1,700 observers deployed around the country. The parallel vote tabulation's estimated results, released on Aug. 11, were consistent with the IEBC's official results [28].

Although NASA dismissed ELOG report as a ploy to legitimize, the findings in the table and the reports made by the observers on the elections, indicated that the observers did "the systematic, comprehensive and accurate gathering of 
information; impartial and professional analysis of information on the election; and the drawing of conclusions based on the high if not highest standards for accuracy of information and impartiality of analysis in the view of the researcher, as envisioned by the United Nations [29]. Looking at the reports of the election observers such as the European Union Election Observer mission (EUEOM), the National Democratic Institute and the International Republican Institutes, the 2007 election of the president of the Republic of Kenya did not meet the free and fair threshold. NDI is a world leader in election monitoring having organized international delegations to monitor elections in dozens of countries, helping to ensure that polling results reflect the will of the people. In its overall conclusion on its observation of the 2007 presidential election which disregarded Article 25 of the ICCPR, the European Union EOM wrote,

The 2007 General Elections in Kenya fell short of key international and regional standards for democratic elections. Most significantly, the electoral process suffered from a lack of transparency in the processing and tallying of results, which undermined the confidence in the accuracy of the final result of the presidential election. Some violence before polling, notably during the nomination phase for parliamentary candidates hampered the conduct of the election, whereas widespread violence with numerous victims after election-day was part of a larger political crisis. This overall conclusion is all the more regrettable, since in advance of the tallying process and despite some significant shortcomings in the legal framework, the elections were generally well administered and freedoms of expression, association and assembly were generally respected. Voters turned out in high numbers for the polling and voted largely peacefully. Moreover and importantly, the outcome of the parliamentary elections appears to command greater confidence by election stakeholders [8].

This observation by the EUEOM is merely diplomatic. Having noted serious irregularities and shortcomings, the EOM concluded that "the elections were generally well administered and freedoms of expressions, association and assembly were generally respected" which were purely cosmetic. Looking the 2002 presidential elections with the year' general elections which were widely accepted by everyone including Kenyatta who conceded defeat way before results were declared, it was not surprising that the media-the state-owned Kenya Broadcasting Corporation (KBC), was biased. This was because it was state-owned and the state used to control information, used it to advance its campaigns and to subsume the opposition in an attempt to manipulate public opinion in favour of its preferred candidate.

The Commonwealth Secretariat election observer mission (EOM) noted that at the time, the private media and the Media Council did not have a voice. The Commonwealth Secretariat EOM wrote,

$\mathrm{KBC}$ 's clear bias in favour of the ruling party was a major issue during the election. The results of a media monitoring exercise conducted by a fellow international observer group confirmed this. It found that since 22 November KBC TV and Radio gave KANU and their candidate Uhuru Kenyatta 33 percentage of TV coverage and a further 32 per cent to presidential duties and campaigning by President Moi, while the NARC coalition and its candidate Mwai Kibaki secured 25 per cent of airtime [3].

The IRI also held similar views based on its findings and in reference to the UNDP assessment of the elections. In its report on the 2007 presidential election it noted,

The United Nations reported that most of the mainstream radio stations provided more coverage to PNU than to the other competing political parties. According to the report the Kiswahili and English services of the state-owned radio station, Kenya Broadcasting Cooperation (KBC), as well as Citizen FM, provided significantly more coverage to PNU than to other parties. In addition, vernacular radio stations provided more coverage to the parties with a perceived following among their listeners (broadcast languages in parentheses): Egessa (Kisii), Kass (Kalenjin), Mulembe (Luhya) and Ramogi (Luo) gave more coverage to ODM than other parties. Musyi FM (Kamba) covered more of ODM-K, while Inooro and Kameme (Kikuyu) provided more coverage to PNU than other parties. Raila Odinga and President Kibaki received the most mentions on most of the radio stations [12].

This was also a show of effectiveness of the MTD EOMs to monitor the processes and outcome of Kenya's presidential elections. Looking at and in comparison, the AU EOM report on the Ghanaian presidential and parliamentary elections held on 7 December 2020, similar observations were made of the state manipulating the media to its advantage. The AU EOM wrote, "Reports received by the Mission reflect that state-owned media granted access to political parties during the electoral campaigns but fell short of providing equal space particularly for smaller parties in line with Article 55:12 of the Constitution [1]" Comparatively, in the 2014 Egyptian presidential elections, Democracy International, an EOM which monitored the elections noted that both statecontrolled and private media favoured the governmentpreferred candidate. It reported thus,

Egyptian media coverage of the election process strongly favored Abdel Fattah El-Sisi. During the campaign period, state-run media are said to have given equal interview airtime to both candidates, but the approach and discourse applied to each candidate differed significantly. Both state and private media engaged in a relentless campaign to bolster turnout in favor of Sisi, often equating abstention with treason and stigmatiz-ing those with opinions differing from the state narrative. This prevented open discus-sion and debate about the election [4].

Comparing with the United States of America, media biasness and biases that could amount to negative publicity on the other better candidate was noted. Organisation for American States EOM reported while noting with concern,

Even though most media maintained a neutral tone 
(sentiment) throughout the electoral campaign in the coverage of both presidential candidates, media outlets overwhelmingly publicly endorsed the democratic candidate. This is compatible with the U.S. legal framework and in particular with Free Speech constitutional guarantees however, TV audiences might not be aware of this editorial policy [22].

\subsection{Multitrack Diplomacy Actors'Accuracy and Impartiality in Monitoring}

Muna \& Hong details the ideal role of international election observer missions arguing that, "They are expected to provide an accurate and impartial reporting or assessment of the quality of elections. They are expected publish their findings and offer recommendations for improvement of future elections. Election observation monitors are also expected to be a symbol of support from the international community to a given country [17]."

It is noted that some domestic observer groups have had success organizing parallel vote tabulations, sometimes called "quick counts", on election night. This is a process through which observers report actual polling station results to a central point, where they are tabulated; the process, if properly organized, can provide a valuable means of checking whether officially announced results accurately reflect what happened at the polling stations [7, 25]. The study findings particularly the compatibility of the views of the voters and the results announced by the EMB reflected the findings of ELOG on the same election and the very. However, ELOG being local might have had its own biases and could have been thought to be biased by Odinga. One of the respondents remarked,

... the local observers' reports could not be taken authoritatively because they have participated in the campaigns first as citizens with political inclinations...to me the international observers have tended to give more credible observation reports than local once... both must be there (Interview, Nairobi, October 23, 2020).

However, The Carter Center EOM, the EU EOM, The Commonwealth EOM, the AU International organizations usually have relied upon quick counts conducted by credible domestic civic organizations. Under certain circumstances, international organizations with capability to build the requisite volunteer networks and data collection systems with the view to conducting reliable quick counts were argued to be able to make an important contribution to electoral processes. This was considered true in highly charged political environments and in situations characterized by time and resource constraints and impairment of local groups from monitoring the elections. EOM among the foreign EOMs that monitored the August 2017 presidential election supported the quick count done by ELOG and this was based on literature advisory as noted:

.... Where both national and international groups are monitoring elections, NDI encourages cooperation. International observer missions support the credibility and development of civil society when they work with local groups and publicly support their efforts and international missions should defend the right of domestic groups to observe elections and conduct quick counts [18].

In view of the argument by Gibson \& Zimmerman, incumbents tend to adopt different legal and illegal to retain power by conducting elections meeting the cosmetic aspects of elections [9]. To this extent, election fraud taints the elections, the case in which the election outcomes lack credibility and integrity; while the 'elected' lack, or use terror to impose legitimacy.

In 2007, running against Kibaki then incumbent Odinga claimed Kibaki rigged the presidential elections (leading to breakout of the famous but unpopular Post 2007 Presidential Elections Violence. Odote \& Musumba observe that contrary to the expectation, the elections turned out to be not credible and not integral; there was dissatisfaction by the electorate who questioned the legitimacy of the president as the country degenerated into violence [23]. But they did not do a study with the electorate.

Since from the results as announced or declared by the EMB, the statistics from the survey tends towards agreeing with the election results, could there have been irregularities in a nutshell? What was the basis for the Supreme Court invalidation of the 2017 presidential election results and nullification of the election calling for a fresh one?

Figure 2 is a photo taken of the researcher interviewing a judge respondent whose views were selected to represent views of the many others, used for analysis on thematic issue in relation to the excerpt, by one of the supervisors during field supervision.

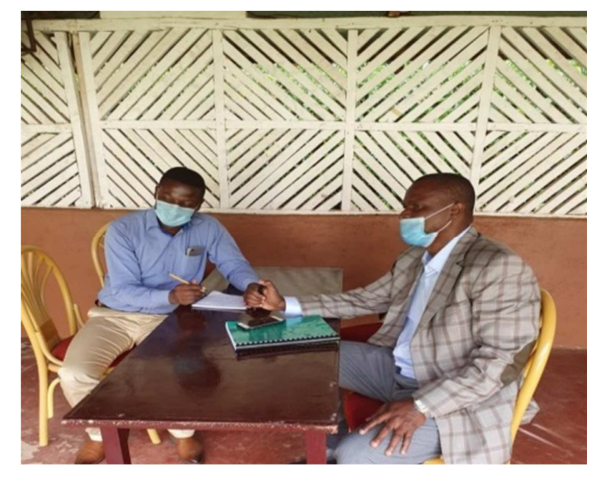

Source: Field Data, 2020.

Figure 2. Researcher left interviewing a Honourable Judge (Interview, Nairobi, July 19, 2020).

According to an honourable judge of the Judiciary of Kenya and a voter who was interviewed as a key informant interviewee observed that election irregularities could have been the possibility for the Supreme Court decision. He charged:

One reason am agreeable to what Supreme Court concluded, I handle the election petitions to an extent of opening the ballot boxes and finding out what is in those ballot boxes and $99.9 \%$ in whatever form you are given... so $100 \%$ the way these elections are conducted there is that perception that there are areas where maybe there 
could be miss-posting of results or intentional variation...those ones you would not miss (Interview, Nairobi, July 19, 2020).

From the submission by the judge, the courts use evidence and procedure as adduced in court and in line with the laws guiding and regulating election process. The Supreme Court decision which annulled the August 7, 2017 presidential elections was based on the process as explained by the judge. The variation in reports and statements of the MTD EOMs such as the Carter Centre which cleared the elections as free and fair, was based on the monitoring process which was limited in a number of ways. The Carter Center admitted that there were 'serious shortcomings'. Although it did not highlight its own, it had challenges including inability to follow up the process electronically which might have bogged down its monitoring. These challenges and inadequacies cut across the MTD EOMs, especially the foreign ones.

Similar position was held by an academic (Ph.D. holder) in the Institute of Diplomacy and International Studies at the University of Nairobi who participated as a key informant interviewee, who held views similar to another senior lecturer at the Institute of Development Studies interviewed almost 2 month earlier. The voter-respondent remarked: "I would go by the court process; it was able to go through all the evidence, to point out some of the irregularities, therefore that tells you that the issue of objectivity is a real issue here" (Interview, Nairobi, September 22, 2020).

The revelation by the respondent who had at the beginning of the interview strongly supported that election observers were important for Kenya's presidential elections that the court process was the way to go in determining the credibility of Kenya's presidential elections, perhaps the observation fell short of the threshold which is highly demanding. During the 2002 electioneering period, the government of the time, of Moi who had planted Kenyatta to succeed him and actually ran on Kenya African National Union (KANU) ticket against opposition candidate Kibaki, Moi is said to have even used state resources to campaign for Kenyatta who was actually just like Moi defending the presidency seat. One such state resource abused by the ruling party then was the media. This was noted in the reports of various election observers. The Commonwealth Secretariat wrote,

Frequencies have been provided for nine TV stations and eighteen FM radio stations so far. The explosion of privately-owned broadcast stations in the main cities in recent years has added a new dimension to the political debate and provided a further theatre for politicking. However only the state-owned Kenya Broadcasting Corporation $(\mathrm{KBC})$ has country-wide coverage and this was used to effects by the ruling party in the campaign [3].

This prompted the Commonwealth Secretariat to recommend against the abuse by the incumbency, the need to sponsor inter-party agreement regarding and the adoption of, the relevant regulations concerning the use of state resources during election campaign and promote a clear distinction between the roles of ruling party politicians as government and as party politicians [3]. In an attempt to understand whether there was an attempt by the government to interfere in the August 2017 presidential election, a number of the key informants observed that there could have been a possibility of such, but did not adduce evidence except analysing the behavious, conduct and utterances of the incumbent president upon the Supreme Court ruling that annulled the elections and order a fresh one. One of the key informants observed while also casting doubts on the credibility of foreign election observers to judge the outcome of Kenya's presidential elections that, "Most of the foreign observers are not familiar with country, the government therefore simply controls them and by and large they tend to endorse outcomes preferred or appealing to their host or as projected to them by their host" (Interview with senior media practitioner, Nairobi, October 22, 2020).

While a number of the foreign observers sent advance teams: long-term observers, two to three months may not be sufficient to walk all the nooks and corners of the country. Even permanent diplomats such as the US Ambassador or the British High Commissioner to Kenya at the time could not pretend to have been familiar with the country. Most of the observation teams therefore relied on the state and the EMB to be 'guided' or 'toured' around as noted in the submissions of the Kenya National Commission on Human Rights and the Independent Electoral and Boundaries Commission (IEBC). This lack of familiarity certainly led to resort to convenient techniques of monitoring resulting in inconsistent and incorrect statements leading to cosmetic judgment of the election processes and outcome.

Another respondent interviewed on a different date in a different environment and from a different background also observed similarly that the government might have lured the observers not to see the real malpractices take place because they tend to blindfold them with diplomatic or state treatment. She charged,

Foreign observers are treated more like state guests and are restricted on where to go and where not to go and they also reciprocate by asking the state where and which source of information is useful for their observation such that it is a tall order...even the state has a candidate in the elections...foreign observers behave like tourists (Interview with an Election Observer, Nairobi, December 5, 2020).

According to the interviewee, not much should be expected from them in terms of the conclusion whether the elections were free and fair and the credibility of the results. Another respondent retorted that:

In fact the observers only observed the voting process and with their limited tool which only looks at how voting took place and whether there was violence or not but not the details on what had been happening at least from the time of voter registration and later during the counting and tallying and they do not access the electronic results transmission system (Interview with an MP, Nairobi, December 5, 2020).

This utterly exposes a large extent of the ineffectiveness of MTD EOMs especially those from the milieu; faults the 
standard monitoring tool which is inconsistent with the technology which is now popularly integrated into the electoral process. It also puts to question the technical capacities of the observer missions or their interests if they had the requisite technology and personnel such as The Carter Center, The Commonwealth, the European Union MTD EOMs and even ELOG.

This view portrays MTD EOMs especially the foreign ones and their observation as Multi-Track Diplomacy trying to preserve or improve cordiality of relations with the host state and internally, promoting a cosmetic situation so as to harmonize with the 'would be desired outcome' for peace and tranquillity within the state so as to promote and maintain the liberal international order, even if the peace were negative. State control of the MTD EOMs of course was either 'given' or beyond the control of the MTD EOMs because they must be accredited and guided by the host state. However, it is also 'chosen' by the MTD EOMs who preferred 'diplomatic treatment/courtesy' to objective monitoring.

\subsection{Election Observers' Reports as Reflection of Presidential Election Outcome}

DRI avers that election monitors should record and report instances of suspicious practices [7]. Therefore, the study sought to the views of voters regarding whether the belief that the statements and reports read and issued by international election observation or monitoring missions reflected the outcome of the presidential elections, 2007-2017. The responses were summarized in Tables 5, 6 and 7.

Table 5. MTD EOMs'reposts against outcome of August 2017 presidential election.

\begin{tabular}{|c|c|c|c|c|c|c|c|}
\hline & & \multicolumn{6}{|c|}{ Do you believe reports by election observer missions reflected the outcome of the August 2017 presidential election? } \\
\hline & & Yes & & No & & Total & \\
\hline \multirow{8}{*}{$\begin{array}{l}\text { Constituency } \\
\text { Name }\end{array}$} & Starehe & 34 & $70.8 \%$ & 14 & $29.2 \%$ & 48 & $100.0 \%$ \\
\hline & Westlands & 22 & $45.8 \%$ & 26 & $54.2 \%$ & 48 & $100.0 \%$ \\
\hline & Dagoreti North & 35 & $72.9 \%$ & 13 & $27.1 \%$ & 48 & $100.0 \%$ \\
\hline & Kibra & 10 & $20.8 \%$ & 38 & $79.2 \%$ & 48 & $100.0 \%$ \\
\hline & Langata & 22 & $45.8 \%$ & 26 & $54.2 \%$ & 48 & $100.0 \%$ \\
\hline & Ruaraka & 31 & $64.6 \%$ & 17 & $35.4 \%$ & 48 & $100.0 \%$ \\
\hline & Embakasi East & 26 & $54.2 \%$ & 22 & $45.8 \%$ & 48 & $100.0 \%$ \\
\hline & Total & 194 & $50.5 \%$ & 190 & $49.5 \%$ & 384 & $100.0 \%$ \\
\hline
\end{tabular}

Source: Field Data, 2020.

From Table 5, majority $194(50.5 \%)$ of the respondents said that they believed that the statements and reports read and issued by international election observation or monitoring missions reflected the outcome of the August 2017 presidential election while $190(49.5 \%)$ of the respondents did not believe. The study sought information on whether voters believed that the statements and reports read and issued by international election observation or monitoring missions reflected the outcome of the March 2013 presidential election. Table 6 details responses.

Table 6. Reports by MTD EOMs on March 2013 presidential election.

\begin{tabular}{|c|c|c|c|c|c|c|c|}
\hline & & \multicolumn{6}{|c|}{$\begin{array}{l}\text { Do you believe the election observation reports on the March } 2013 \text { presidential election reflected the } \\
\text { outcome of the elections? }\end{array}$} \\
\hline & & Yes & & No & & Tota & \\
\hline \multirow{8}{*}{$\begin{array}{l}\text { Constituency } \\
\text { Name }\end{array}$} & Starehe & 30 & $62.5 \%$ & 18 & $37.5 \%$ & 48 & $100.0 \%$ \\
\hline & Westlands & 36 & $75.0 \%$ & 12 & $25.0 \%$ & 48 & $100.0 \%$ \\
\hline & Dagoreti North & 39 & $81.3 \%$ & 9 & $18.8 \%$ & 48 & $100.0 \%$ \\
\hline & Kibra & 11 & $22.9 \%$ & 37 & $77.1 \%$ & 48 & $100.0 \%$ \\
\hline & Mathare & 15 & $31.3 \%$ & 33 & $68.8 \%$ & 48 & $100.0 \%$ \\
\hline & Ruaraka & 32 & $66.7 \%$ & 16 & $33.3 \%$ & 48 & $100.0 \%$ \\
\hline & Embakasi East & 25 & $52.1 \%$ & 23 & $47.9 \%$ & 48 & $100.0 \%$ \\
\hline & Total & 210 & $54.7 \%$ & 174 & $45.3 \%$ & 384 & $100.0 \%$ \\
\hline
\end{tabular}

Source: Field Data, 2020.

From Table 6, majority $210(54.7 \%)$ of the respondents said that they believed that the statements and reports read and issued by international election observation or monitoring missions reflected the outcome of the March 2013 presidential election while 174 (45.3\%) of the respondents did not believe. The study interrogated whether voters believed reports by international election observation or monitoring missions reflected the truth outcome of the December 2007 presidential election, not the official results as declared by ECK. The responses were analyzed by constituency, number of times voted and level of education and presented as shown in Table 7. 
Table 7. MTD EOMs reports read against results by ECK on Dec 2007.

\begin{tabular}{|c|c|c|c|c|c|c|}
\hline & \multicolumn{6}{|c|}{$\begin{array}{l}\text { Do you believe statements and reports of election observers reflected the truth about outcome of the December } 2007 \\
\text { presidential election against the official results declared by ECK? }\end{array}$} \\
\hline & Yes & & No & & Total & \\
\hline Starehe & 29 & $60.4 \%$ & 19 & $39.6 \%$ & 48 & $100.0 \%$ \\
\hline Westlands & 39 & $81.2 \%$ & 9 & $18.8 \%$ & 48 & $100.0 \%$ \\
\hline Dagoreti North & 38 & $79.2 \%$ & 10 & $20.8 \%$ & 48 & $100.0 \%$ \\
\hline Kibra & 42 & $87.5 \%$ & 6 & $12.5 \%$ & 48 & $100.0 \%$ \\
\hline Langata & 40 & $83.3 \%$ & 8 & $17.7 \%$ & 48 & $100.0 \%$ \\
\hline Mathare & 37 & $77.1 \%$ & 22.9 & $35.4 \%$ & 48 & $100.0 \%$ \\
\hline Ruaraka & 38 & $79.2 \%$ & 10 & $20.8 \%$ & 48 & $100.0 \%$ \\
\hline Embakasi East & 32 & $66.7 \%$ & 15 & $33.7 \%$ & 48 & $100.0 \%$ \\
\hline Total & 295 & $76.8 \%$ & 89 & $23.2 \%$ & 384 & $100.0 \%$ \\
\hline
\end{tabular}

Source: Field Data, 2020.

From Table 7, majority $295(76.8 \%)$ of the respondents believed that the statements and reports read and issued by international election observation or monitoring missions reflected the truth on the outcome of the December 2007 presidential election against the official results declared by the EMB (ECK) against the belief of 89 (32.6\%) voters.

Examining the reports of elections observers and in line with their observation on the processes and outcome of the elections, a lot of facts emerged confirming theoretical position that election monitors should record and report instances of suspicious practices; to help promote and protect the civil and political rights of the voters and the candidates and lead to correction of errors or weak and poor practices when elections are still underway [7].

This revelation implies that the election observers' reports (The Carter Center, AU EOM, EUEOM, Commonwealth EOM, COMESA EOM (COMESA, 2017) and ELOG statements and reports in concurrence with the declared results could have been genuine, the $1 \%$ percentage difference between the voter-respondents who believed the reports were genuine and those who held contrary belief is significant in the sense that by simple judgment, majority of the voters $(50.5 \%)$ believed the reports which were in consonance with the results declared by the EMB; and is in consonance with the results of those who believed their votes counted, their sovereign will was expressed and safeguarded (51.3\%). Similar observation was made by ELOG, a citizen election observation group, as reported by The Carter Center.

Regarding the outcome of the 2007 presidential election, the European Union alongside other observers, was able to observe irregularities and noted therefore, that,

Constituency results were announced mostly on the basis of telephone calls and faxes rather than original result forms as required by law. Inconsistencies were identified between the presidential election results announced at the constituency level and those announced at the national level. At the ECK headquarters, the EU EOM Chief Observer was shown forms on which the election results for two constituencies had been changed without any written justification for the changes (EU EOM, April, 2018).

This observation identified procedural flaws. The EOM identified electoral irregularities and detected fraud. The IRI wrote,

Although IRI's observer mission consisted of only shortterm observers who were unable to be present through all of the vote tallying at the constituency level, IRI has reason to believe that electoral fraud took place and condemns that fraud. The rigging and falsifying official documentation constitutes a betrayal of the majority of the Kenyan people who peacefully and patiently waited in long lines to vote on December 27 [12].

The EOM admitted inadequacy on its end but downplayed it as insignificant: failure to arrive in the country in advance. The EOM, much as the findings of most of the MTD EOMS both local and foreign pointed to irregularities as fraud, it relied on convenient techniques to judge the elections, whose results were generally and acceptably flawed.

According to the Johan Kriegler-led Independent Review Commission (2008), in the period leading to the 2007 elections, campaign were rigorous robust based on ethnic hate-speech divisive language degenerating into violence. Odinga had lost hope in the EMB whose reconstitution by Kibaki a few days to elections cast doubts on its professionalism and impartiality. In addition, the credibility and integrity of the results remained highly questionable charging that the rigging took place at the polling stations so making it difficult to detect at the national tallying centre. The results were so inaccurate [14]. Ongoro (2010) charges that;

It will be recalled that the 2007 Kenya elections wrecked of all manner of chicanery characterized by the brazen attempt to disenfranchise the electorate and announce fictional results in areas where no elections took place, not to mention intimidation of the electorate by the police and military in many places - this was the crawling point of democracy in Kenya [24].

Against this bleak background, the outcome did not reflect the will of the people (Waki Report, 2008; Kriegler Report, 2008). Ranking the elections in terms of extent of electoral irregularities and outcome fraud, December 2007 ranked highest with the largest number of voters holding the view. Figure 3 is a pie chart used to enhance understanding of the analyses and interpretations. 


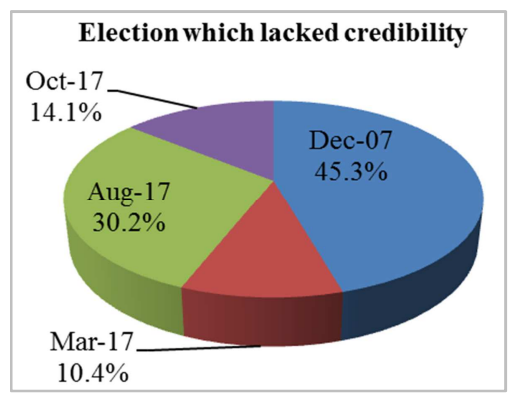

Source: Field Data, 2020.

Figure 3. Pie chart on the presidential election that was not credible.

From figure 1, the December 2007 presidential election conducted along the general election, ranked highest in terms of which of the elections the respondents believed the votes did not count and that presidential elections outcome was not credible. This is demonstrated by the majority $174(45.3 \%)$ of the 384 respondents represented by the blue segment of the pie chart.

\section{Conclusion}

On the effectiveness of MTD monitoring in critical assessment of Kenya's presidential election outcomes, the study concluded that the reports of election observers reflected the electoral process as it unveiled and the processes and activities of MTD actors in observing them and reflected the outcome of the elections. Generally, election observers remained important to the safeguarding of the will of the voters. The MTD actors were able to sight and cite electoral irregularities as reflected in their reports on the elections. The Supreme Court of Kenya nullification of the August 2017 presidential election results was an indication of electoral irregularities which cited in their reports. MTD EOMs were not responsible for the irregularities or failure to prevent them, the EMB was. The MTD monitors did cry of difficulties to access critical information such as the tallying technology employed by the EMB. Generally, for the stated capacity inadequacies including inability to provide an accurate and impartial reporting or assessment of the quality of elections, MTD election monitors for the August 2017 presidential election failed to uncover illegal and dishonest practices during the elections and only ended up conferring legitimacy on irregularly conducted presidential election. Overall however, there was a strong positive association between capacity of multi-track diplomacy election monitors and credibility of monitoring reports as regarded Kenya's presidential elections, 2007-2017.

\section{Recommendations}

In regards to MTD actors' capacities for the systematic, comprehensive and accurate monitoring of Kenya's presidential elections, MTD is efficacious tool for critical assessment of Kenya's presidential election outcomes but had flaws of slightly more than $40 \%$. Observer missions' reports could be used to settle electoral disputes but their value should be persuasive not conclusive. In addition, the reports could be adopted by the
EMB to improve its works in future elections. A holistic review of the UN regimes governing election observation was necessary. Locally, the current electoral laws should be amended to enhance the rights and duties of election observers to allow them full access for effective election observation. Therefore, there is need to define terms and conditions and the threshold as well without which observers may not be accredited and if accredited, then their reports may not bear until they comply. The African Union EOM and Commonwealth EOM must desist from interfering in elections and stop the mere conferment of the free and fair and credible fanfare without objective monitoring. The domestic observation teams could be more effective, reliable and credible so should be supported financially and technically and be protected to gain access to every detail of processes of the EMB from voter education to technologybased electoral infrastructure.

\section{Acknowledgements}

We thank the Almighty God for good health, wisdom and knowledge that enabled us to write this article. We thank the editorial team for accepting this work.

\section{References}

[1] African Union. (2020). African union election observer mission to the 7 December 2020 presidential and parliamentary elections in Ghana (Preliminary Report). https://au.int/en/pressreleases/20201204/arrival-head-africanunion-election-observation-mission-ghana.

[2] Commonwealth Secretariat. (2018). Kenya General Elections 7 August 2017: Report of the Commonwealth Observer Group. Commonwealth Secretariat. https://books.thecommonwealth.org.

[3] Commonwealth Secretariat. (2006). Kenya General Election 27 December 2002. Commonwealth Election Reports. https://books.thecommonwealth.org.

[4] Democracy International. (2014, July). Egypt presidential election observation report. Democracy International Inc.

[5] Diamond, L. \& McDonald, J. (1996). Multi-track diplomacy: A Systems Approach to Peace. Kumarian Press.

[6] Damdinjav, M., Garcia, I., Lawson, E., Margolis, D. \& Nemeth, B. (2013 Spring). Institutional failure in Kenya and a way forward. Journal of Political Inquiry, 1-25. New York University.

[7] DRI. (2011). International consensus Essential elements of democracy. Democracy-reporting.org. https://democracyreporting.org/dri_publications/international-.

[8] European Union Election Observer Mission Kenya. 2017. (2018). Republic of Kenya 2017 general Elections final report (10 January 2018). http://www.eods.eu/library/eu_eom_kenya_2017_preliminary _statement_31_october_final.p̄pdf.

[9] Gibson, C. and Zimmerman, B. (2015). Democratization in Africa. In Oxford Bibliographies in Political Science. Ed. Sandy Maisel. Oxford University Press. 
[10] Hyde, S. D. (2011). Catch Us If You Can: Election Observation and International Norm Diffusion. Midwest Political Science Association. Doi: 10.1111/j.15405907.2011.00508.x.

[11] Independent Electoral and Boundaries Commissions, Kenya. (2018). Independent Electoral and Boundaries Commission post- election evaluation report: For the 2017 general election and the fresh presidential election. IEBC Kenya.

[12] International Republican Institute. (2008a). Election Observation Report: Kenya's 2007 Presidential, Parliamentary and Local Elections. http://www.iri.org/sites/default/files/Kenya\%27s\%202007\%20 Presidental,\%20Parliamentary\%20and\%20Local\%20Elections .pdf.

[13] Kelley, J. (2009). D-Minus Elections: The Politics and Norms of International Election Observation. International Organization, 63, no. 4, 765-787.

[14] Kelley, J. (2010). Election observers and their biases. Journal of democracy, 21 (3), 158-172.

[15] Kriegler, J. \& IREC. (2008). Report of the Independent Review Commission on the General Elections held in Kenya on 27 December 2007. IREC.

[16] Mapendere, J. (2000). Track one and a half diplomacy and the complementarity of tracks. COPOJ - Culture of Peace Online Journal, 2 (1), 66-81. Carter Center.

[17] Muna \& Hong, N. and Hong, D. U. (2017). International Observers, and the Monitoring of National Elections. In: Democracy and Electoral Politics in Zambia., 313-333. https://doi.org/10.1163/9789004430440_014.

[18] National Democratic Institute (2002). NDI Election Watch, Kenya 2002 elections. National Democratic Institute. https://www.ndi.org.

[19] Natolooka, K. (2017). The efficacy of multi-track diplomacy in resolving intrastate and internationalized conflicts in Africa: the case of the 2007/2008 post-election violence in Kenya (Doctoral dissertation). Rhodes University.

[20] Nginya, M. (2018). "International election observers in Kenya's 2017 elections: Impartial or partisan?” Journal of African Elections. doi: 10.20940/JAE/2018/v17i1a3.

[21] Norris, P, Frank, W. R., \& Coma, i M. F. (2013 October). Assessing the Quality of Elections. Journal of Democracy, 24 (4), 124-135. The Johns Hopkins University Press. doi: 10.1353/jod.2013.0063.

[22] OAS. (2020). Preliminary statement of the OAS electoral observer mission for the November 3, 2020 general elections in the United States of America. OAS Press.https://www.oas.org/en/media_center/press_release.asp? $\mathrm{sCodigo}=\mathrm{S} 020 /$.

[23] Odote, C. \& Musumba, L. (Eds) (2016). Introduction. In C. Odote \& L. Musumba (Eds.), Balancing the scales of electoral justice: 2013 Kenyan election disputes resolution and emerging jurisprudence. International Development Law Organization (IDLO) and Judicial Training Institute (JTI).

[24] Ongoro, L. A. (2010). Democracy and elections in Africa: the case of Kenya, 2007 - 2012 (Master's project).

[25] OSCE/ODIHR, (2004). Handbook for Monitoring Women's
Participation in Elections. OSCE/ODIHR. https://www.osce.org/odihr/elections/13938.

[26] Otieno, F. (2015). New constitution, same old challenges: reflections on Kenya's 2013 general elections. Society for International Development (SID)/ Uraia Trust.

[27] Shah, S. (2015). Local versus international standards of elections assessment: Kenya's 2013 general elections. In F. Otieno (Ed). New constitution, same old challenges: reflections on Kenya's 2013 general elections (36-46). Society for International Development (SID)/ Uraia Trust.

[28] The Carter Center (2018). Kenya: Final Report, 2017 Kenya General and Presidential Elections. https://www.cartercenter.org/news/pr/kenya- 030718.html.

[29] United Nations. (2005). Secretary-general endorses principles for election observation, calls on international community to make full use of guidelines. https://www.un.org/press/en/2005/sgsm10190.doc.htm.

\section{Biography}

David Owuor Okoth Sanmac is a Ph.D. candidate, Department of Peace and Conflict Studies, School of Disaster Management and Humanitarian Assistance, Masinde Muliro University of Science and Technology, Kakamega, Kenya. He holds M.A. in International Relations and B.A. in International Relations and Diplomacy. He part-time lecturer of Diplomacy and International Relations (Masinde Muliro University of Science and Technology) and Rev. Father (Religious) of Legio Maria of African Church Mission. He is co-author of an article titled, Critiquing The Term Abnormality As It Relates To Terrorism, a publication in Asian Journal of Social Sciences \& Humanities Vol. 9 (1) Feb-May 2020.

Pontian Godfrey Okoth is full professor at Department of Peace and Conflict Studies, School of Disaster Management and Humanitarian Assistance, Masinde Muliro University of Science and Technology, Kakamega, Kenya. He is former Vice Chancellor of Lugazi University, Uganda. He holds Ph.D. in Diplomatic History from the University of California, Los Angeles, United States of America. The professor has more than 170 publications including books, book chapters, edited books and journal articles. $\mathrm{He}$ is a renowned academic and mentor to many professors, postdoctoral, doctoral, masters and undergraduate students. He is the main supervisor to Sanmac.

Elijah Onyango Standslause Odhiambo is lecturer of Diplomacy and International Relations, Department of Political Science and International Relations, School of Arts and Social Science, Bomet University College, Bomet, Kenya. An Anglican Priest, Odhiambo also serves in the Chaplaincy of the University College. Previously, Odhiambo taught in the Department of Peace and Conflict Studies, School of Disaster Management and Humanitarian Assistance, Masinde Muliro University of Science and Technology, Kakamega, Kenya. He has 63 publications. Odhiambo has been instrumental in the academic mentorship of many doctoral, masters, and undergraduate students. Currently, he is the second supervisor to Sanmac. 